\title{
Executive Immunity in Nigeria: Putting Off Old Garments
}

\author{
Ibraheem Ojo Tajudeen ${ }^{1}$ \\ ${ }^{1}$ Acting Dean, Faculty of Law, Adekunle Ajasin University, Akungba Akoko, Ondo State, Nigeria \\ Correspondence: Ibraheem Ojo Tajudeen, Acting Dean, Faculty of Law, Adekunle Ajasin University, Akungba \\ Akoko, Ondo State, Nigeria. Tel: 234-802-336-2799. E-mail: taju.ibraheem@yahoo.com
}

Received: May 27, 2013 Accepted: June 7, 2013 Online Published: August 30, 2013

doi:10.5539/jpl.v6n3p189 URL: http://dx.doi.org/10.5539/jpl.v6n3p189

\begin{abstract}
The idea of immunity from legal process is, as a general rule, abhorrent to modern legal civilization. The origin of this class of immunity traces back to the era of absolute monarchs, when it was believed that a king could do no wrong, thus the term sovereign immunity, of which the expression 'executive immunity' is a derivative. This paper examines, albeit briefly, the constitutional immunity from prosecution conferred on certain political office holders in Nigeria. The order of progression of this paper shall be an examination of the concept of immunity followed by its uses and abuses in Nigeria, some arguments for and against its retention in the Constitution, comparative analysis of the position in a few other countries, a brief consideration of the rule of law and finally some recommendations and conclusion.
\end{abstract}

Keywords: executive, immunity, constitution, law, corruption, argument

\section{The Concept of Immunity}

The earliest concept of sovereign immunity provided absolute immunity for the monarch, that is, the "king can do no wrong." The doctrine of sovereign immunity applies to limitation of government rather than personal liabilities. This does not mean that the president or other high public officials should not have any immunity in the faithful discharge of their public duties. Executive immunity has a place to the extent that it helps to foster effective governance by shielding some members of the executive arm of government from frivolous civil lawsuits arising from the discharge of their public duties.

Black's Law Dictionary (Note 1) defines immunity as an exemption from a duty, liability or service of process, especially such an exemption granted to a public official. Quoting Kionka,(Note 2) it goes further thus:

'An immunity is a defence to tort liability which is conferred upon an entire group or class of persons or entities under circumstances where considerations of public policy are thought to require special protection for the person, activity or entity in question at the expense of those injured by its tortious acts ...'

Section 308 of the 1999 Constitution of the Federal Republic of Nigeria provides as follows:

(1) Notwithstanding anything to the contrary in this constitution but subject to subsection (2) of this section-

(a) No civil or criminal proceedings shall be instituted or continued against a person to whom this section applies during his period of office;

(b) A person to whom this section applies shall not be arrested or imprisoned during that period either in pursuance of the process of any court or otherwise; and

(c) No process of any court requiring or compelling the appearance of a person to whom this section applies, shall be applied for or issued;

Provided that in ascertaining whether any period of limitation has expired for the purposes of any proceedings against a person to whom this section applies, no account shall be taken of this period of office.

(2) The provisions of subsection (1) of this section shall not apply to civil proceedings against a person to whom this section applies in his official capacity or to civil or criminal proceedings in which such a person is only a nominal party. 
(3) This section applies to a person holding the office of president or vice-president, governor or deputy governor; and the reference in this section to "period of office" is a reference to the period during which the person holding such office is required to perform the functions of the office.

The overall effect of Section 308 of the 1999 Constitution is that the elected officers mentioned in Subsection (3) of the section are protected from arrest, prosecution, imprisonment, civil and criminal proceedings while their tenure lasts. And if there has been a case standing against any of them before being elected into office, such a case shall terminate or at least be put in abeyance during the continuation of their tenure in office.

By section 5 of the 1999 Constitution, the executive power is conferred on the President at the Federal level and on the Governor at the State level. The immunity granted to the officers named in section 308 is personal and not official. It is also an absolute one; one that covers all criminal and civil claims against the beneficiary during his/her tenure in office.

Section 308 of the 1999 Constitution is a provision put in place to enable a Governor while in office to conduct the affairs of governance free from hindrance, embarrassment and the difficulties which may arise if he is being constantly pursued and harassed with Court processes of a civil or criminal nature. It is a provision designed to protect the dignity of office. Section 308 cannot however be relied upon to deny a citizen access to court especially where the nature of the suit is such that the RES in dispute will be destroyed permanently with the effluxion of time. (Note 3)

Section 308 does not protect a Governor or President from legal proceedings in a matter of his election per se or in a matter connected with his election even when he as contestant has been declared duly elected or returned as Governor. Election Petitions and election related proceedings are special proceedings within the intendment and context of Section 308 of the Constitution. The immunity is not within the contemplation of such proceedings. To hold that Section 308 can be invoked in a matter relating to the eligibility for a political office where the tenure of such office has been set out in the Constitution will translate into denying a Plaintiff his right of access to the Court. It is only in a case where a deferment of a plaintiff's right of action is not likely to destroy the RES in the suit that section 308 can be invoked. (Note 4)

Again, section 308 was not crafted or designed to encourage injustice or deprive an aggrieved party the exercise of his right to a remedy under the law. Thus it provides no immunity to a governor whose election is being challenged in court. No one should contend that he wants to enjoy some benefit of his illegality.

In IMB v Tinubu, (Note 5) although the action was instituted against the appellant as a private citizen, he had cause to file an appeal against an interlocutory decision of the trial court in the suit. It was during the pendency of this appeal that the appellant was sworn in as the governor of Lagos State. By virtue of this and the provision of Section 308 of the constitution, the suit was rendered incapable of being continued against the appellant during his period of office as governor of Lagos State. The constitutional immunity admits of no waiver by the appellant or by any incumbent of the relevant offices stipulated under the section, for the section prescribes an absolute prohibition to any court during the period of office of the holder of the posts described to entertain any claim for relief against such person. (Note 6) The immunity is not that of a person of the appellant, but of the particular state which he represents during the tenure of his office. All courts are bound in appropriate cases to give effect to the said immunity. It does not matter whether or not such immunity is pleaded or relied on by the parties to any proceedings. Even when the governor was the one pursuing the interlocutory appeal, to allow him proceed with such would amount to continuing the substantive suit in which he was a defendant. The only permissible proceedings are when such a person is sued in his official capacity and when he is a nominal party.

The specified officers are also immune from arrest or imprisonment. No court can lawfully exercise any jurisdiction on them and no court can claim ignorance of the provisions of the section. The only way to give effect to the provisions of the section is to decline jurisdiction in any process or proceeding which is capable directly or indirectly of affecting the persons occupying the offices stated. (Note 7) It is the substance of the action that determines whether an official who enjoys immunity is sued in his official or personal capacity and not the mere use of his name. (Note 8)

It is pertinent to note, however, that this section does not prevent these officers from suing other people. (Note 9)

\section{The Uses and Abuses of the Immunity Clause in Nigeria}

It must be said that immunity from prosecution is a well-founded and well-reasoned concept which has sundry benefits when applied honestly and scrupulously for the greater good and benefit of the society. A sitting state Governor of Nigeria or the President, during the subsistence of his term of office, must have a free hand to act boldly and courageously for public good. In doing so, such Governor or President would not be hindered by fear 
for self, for repercussion of actions embarked upon, for general public interest of a state or for national interests clearly defined. All legitimate actions undertaken during the pendency of term of office by a Governor or President must therefore be foreclosed from personal legal liability, hence the concept of immunity. (Note 10)

Immunity from prosecution is subject to abuses; just as every other law or rule is subject to abuse and adulteration by persons with such disposition to manipulate and corrupt laws and rules for their personal benefit, instead of public benefit. It is the case, therefore, that a governor or president, desirous of subverting public interests and public good for evil and personal gain, could engage in actions that serve personal or parochial interests, which of course amounts to perversions of public and national interest. At the same time, such governor may seek to cloak himself in immunity from prosecution for actions undertaken as a public official. The electorate has witnessed repeat demonstrations of such abuse of immunity protections since 1999. (Note 11)

It is a well-known fact that corruption and abuse of power by past and present members of the executive and other arms of government have retarded development and progress in our country. The immunity clause in our Constitution is and has been an impediment in the war against corruption. The call for its removal pivots around the belief by a majority of the citizenry that for Nigeria to move forward in her fight against corruption, the immunity clause needs to be amended or removed altogether.

That immunity promotes corruption may not be totally true if one considers the following: corruption is a crime, a crime is committed against the State (whether Federal or State), and the State proceeds against the offender through its law officers. The Attorney-General of the Federation (AGF) is appointed by the President while the Governor appoints the Attorney General of the State. Sections 174 and 211 of the 1999 Constitution provide for the powers of the AGF and Attorneys General of the States respectively. These powers are that they can institute and undertake proceedings; take over and continue; and discontinue proceedings at any stage before judgment. Within the Nigerian context, to allow them prosecute their 'benefactors' will be a herculean task. Abrogating the immunity clause and allowing Attorneys General to prosecute whether on corruption or other crimes will serve two unpleasant ends. In the first place, an Attorney General will refuse to prosecute either the Governor or the President as the case may be unless such Attorney General wants to risk losing his job. Secondly, an Attorney General can be used against a perceived political opponent where such an opponent does not enjoy immunity. For example, the President can use the Attorney General of the Federation against his vice President and Governors he considers opposing him politically; so also a Governor can use the state Attorney General against his deputy Governor if the two of them operate on different political wave lengths. This was clearly evident during the Obasanjo years. So this may create more problems than it seeks to solve. (Note 12)

On the one hand, immunity from prosecution allows freedom of action by those beneficially protected with such immunity protections; conversely, immunity - when abused - could quickly become instruments of impunity of actions and impunity of outcomes, especially in the hands of public officials who seek to formulate and impose fraudulent public policies on Nigerian citizens. Immunity from prosecution could become a dangerous tool in the hands of those who possess a perverse sense of law, ethics, and decency. (Note 13)

Corrupt political leaders will of course make efforts to see that the immunity clause is retained in the Constitution. That is the cloak under which they have hidden for years perpetrating their crimes against the Nigerian people, sneering at and insulting our laws and institutions and collective intelligence. The Immunity Clause is a license for stealing, killing and maiming.

The constitutional drafting committee meant well when section 308 was added to the 1999 constitution of Nigeria. But they did not know that the provision contained therein would be abused and used to the disadvantage of the people by the VIPs. It appears the immunity clause in the Constitution has outlived its uses and needs to be removed.

\section{Arguments for and Against its Removal from the Constitution}

Citizens who have become worried by the abuse of the clause have postulated that it should have no place in the constitution and its removal will not in any way affect governance negatively. They are always quick to point out that there was no immunity in the First and Second Republics and there were no distractions then. It was even pointed out that there were no frivolous cases in court then. They also argued that the removal of the clause would help to keep the leaders in check. (Note 14) Moreover, the distraction if any, that would arise cannot be compared to the grandiose looting that is being perpetrated as a result of the immunity being enjoyed, especially by Governors. The earlier the corrupt politicians are stripped of immunity against prosecution, the better. In a country ridden by corruption, embezzlement, lack of accountability and outright looting, the presence of an immunity clause in the Constitution is like building a shield or military bunker for rogues. Right now, the Senate President, the Speakers of the House of Representatives and State Houses of Assembly and the Chairmen of the 
774 Local Governments in Nigeria do not have any immunity but there is not a single case of malicious legal action or prosecution against any of them. Any State official that conducts his state functions transparently will not encounter any malicious prosecution because Nigerians are not bloodhounds.

The Nigerian Constitution presently offers carte-blanche immunity protections to the President and Governors. Nigeria ought to review these provisions and sections of the Constitution to repeal completely or to make amendments that reflect standards or thresholds of conduct warranting such absolute constitutional protections, thresholds beyond which the prosecutorial door is open and the immunity protection door is slammed in the face of erring public officials. But this must clearly distinguish categories of actions that may be undertaken in good faith by, say, a Governor or President in the public interest, while such Governor or President is in office.

Furthermore, and perhaps the most important, is the fact that majority of Nigerians want this clause removed. Many of us believe that its removal will bring a great measure of sanity to governance and will prevent these office-holders from seeing themselves as above the law and as mini-gods, who can do and undo, playing with millions of human lives. It will prevent crooks, who have been convicted for all kinds of offences in foreign countries and in Nigeria from even nearing a ballot box to contest. Removal of the immunity clause will also mean that executives will not be able to instigate violence and murder against political opponents. Right now, we know that several state governors are behind militancy, thuggery and murder, and if the immunity clause is removed, even if they are not directly involved in these crimes, they can be hauled in by association. (Note 15) For transparency and good governance to be enthroned in the polity, some portions of the constitution such as the immunity clause have to be removed. This was the common thread that ran through community meetings organised by the National Assembly in different parts of the country recently in respect of the review of the 1999 constitution.

The Nigerian Constitution was prepared by people most of whom were actuated by self-interest and personal ambition. They knew they would run for office, and if they won or rigged their way in, they planned to loot the treasury; so it was in their interest to install for their own protection immunity from prosecution. Today the same ilk of people, with the same species of interest and ambition, dominate the Nigerian political sphere. The removal of this clause will act as a deterrent, no matter how small this effect will be, to others with the aim and intent of going into politics or government to make money. In most cases, a lot of die-hard politicians, who do not have any means of income, except politics, will not be able to make their way into office by crooked means. It is not surprising that not satisfied after eight years as Governors, some of them, under the pretext of still wanting to serve Nigeria, are now Senators or Ministers.

An analyst is of the opinion that removing the immunity clause will have little or no effect, because we still have the same Nigerians in the system, who will now seek to rely on god-fathers and an inefficient and corrupt judicial system. But every little helps, so they say. If the removal of immunity is going to contribute only 2 percent to the fight against corruption, so be it. We cannot just sit there and let these people kill us while we put it in God's hands. If its removal creates fear in their hearts, and they still risk committing crimes against the Nigerian people, at least the fear of God has been put in their hearts, and if caught, they will be dealt with severely, harshly and appropriately by the people. (Note 16)

Normally, in a normal country with well-behaved political leaders, there would not be a problem with retaining such a clause, in fact, strengthening it, but in a corruption-ridden society such as ours, it has proved to be more evil than good. Nigerians know how the clause has been abused by irresponsible politicians, and the consequences on our society. It has caused untold sufferings to Nigerians. Virtually every sector of the economy is comatose. Only corruption and other vices appear to and are actually thriving.

It has also been argued that instead of removing the immunity clause to be able to go after them while they are still in power, we have other checks and balances in the Constitution. The impeachment clause under sections 143 and 188 of the 1999 Constitution as it affects the president and the vice-president; and the governor and his deputy respectively should be explored. Experience has shown in Nigeria that it is not only protected officers that are corrupt. There have been cases of graft against Local Government Chairmen and other public officers who are not protected by Section 308. These include Directors of parastatals, ministers and so on. If these people who are not protected are as corrupt as the protected ones, then the problem lies somewhere else and probably not with the immunity clause. Politics has beclouded our quest for fighting corruption. In most cases it is just a matter of belonging to the ruling class and you get off the hook of anti-graft agencies.

It is almost certain that if we remove the immunity clause from the constitution, the incumbent governors or the president would use the power of incumbency to fight his cases. How many judges would be courageous enough to hear and determine cases against the president? Which prosecutor would be courageous enough to even 
institute the case? It is the incumbents that appoint the Attorneys General. During the fight for and against Obasanjo's 3rd term scheme, we know what the country went through when he wanted to use his power of incumbency to amend the Constitution to buy another four years. If we cannot easily put them away in jail after their tenure have expired and lack executive immunity, how can we put them in jail when they still have the incumbency powers and all the trappings of office?

It is true that a removal of the clause will give an excuse to an officer that is not ready to work as he will continue to let the world know that he wants to perform but some people have taken him to court. We have experienced are still experiencing this. Many governors who were dragged to Election Petition Tribunals immediately after their elections cried out that they were distracted and that they needed to settle down to work. Some still have electoral cases pending against them and they have consistently argued that these cases put them under pressure and did not allow them to function optimally. We may face more of such excuses if the immunity clause is expunged from the Constitution. (Note 17)

It has also been pointed out that removing the immunity clause as a means of reducing graft will neither work nor make any difference because there are laws and institutions that should tackle graft and they have not been able to achieve much. (Note 18) Numerous anti-graft bodies exist, in addition to the regular courts. The anti-graft bodies are not making much impact. Nigerian politicians will always find a loophole to commit their crimes against the Nigerian people, irrespective of any law imposed on them.

In the light of proven cases of corruption among some beneficiaries of the immunity clause, is there still any point in having the clause in our constitution? In whose interest would it be for the State to allow a corrupt Governor, Deputy Governor, President or Vice President to continue to amass wealth corruptly while in power while the State waits for him to step down from office before he could be tried? While the concept of immunity and its provision in our 1999 constitution might be appropriate, it must be balanced with our contemporary political realities. Placed therefore on a scale, does the removal of immunity on account of corruption by beneficiaries displace the age old rationale of providing immunity from prosecution from high office holders?

\section{Comparative Analysis of the Position in Other Jurisdictions}

\subsection{United States of America}

The US Constitution contains only one expressed immunity clause in Article 1 Section 6. It provides that,

"The senator and representatives...shall in all cases, except treason, felony and the breach of the peace, be privilege from arrest during their attendance at the session or their respective houses, and in going to or returning from the same, and for any speech or debate in either house, they shall not be questioned in any other place."

Article II, Section 4 of US Constitution states that: The President, Vice President and all civil Officers of the United States, shall be removed from Office on Impeachment for, and Conviction of, Treason, Bribery, or other high Crimes and Misdemeanours. This implies that they must have been tried and found guilty before impeachment process will commence. If they are immunized against investigation and prosecution (civil and criminal) as stated in Nigeria's Constitution, this will not be possible. Article III, Section 2 of US constitutions even goes further to state that they will be tried by Jury not by court. The Trial of all Crimes, except in Cases of Impeachment, shall be by Jury; and such Trial shall be held in the State where the said Crimes shall have been committed; but when not committed within any State, the Trial shall be at such Place or Places as the Congress may by Law have directed.

Although the US Constitution goes no further in enumerating any additional immunity for the executive branch (in Article II), the US Supreme Court, in Jones v. Clinton, ruled that the executive branch has qualified executive immunity to enable it discharge its duties without concern that a particular action may result in civil liabilities from its actions. The court also held that the president does not have absolute immunity on unofficial acts. While there are different legal opinions about the President, there is consensus that the Vice President and other high public officers, including state governors can be indicted and prosecuted while in office, before any impeachment proceedings. (Note 19)

The US is arguably one of the oldest democracies in the world and she has realized that immunity in any form does not have a place in its scheme of things as the law must never be compromised. While ruling on the issue of immunity the Court of Appeal, per Bowman J. in Clinton v Jones, held that the president, like all other government officials, is subject to the same laws that apply to all other members of our society and that he could find no case in which any public official had ever been granted any immunity from suit for his unofficial acts. 
The US Constitution does not confer wide ranging immunity to Federal and State Executives from prosecution. For example, in 2005, the Governor of the State of Connecticut, Mr. John G Rowland, was found to have received gratifications totaling $\$ 100,000$, not even in cash, but by accepting free chartered trips and vacations and renovations to his cottage. The FBI immediately descended on him and did not wait for his gubernatorial term to expire because of an "Immunity Clause" as we have in Nigeria. He had to resign and upon this, was put on trial and eventually sent to a year in jail, after he himself admitted betraying the trust of the people he was meant to serve. (Note 20)

The United States constitution allows investigations of public office holders. President Andrew Johnson was indicted of power abuse and was later impeached in 1868. Richard Nixon was investigated and indicted of misuse of power and obstruction of justice. He resigned to pre-empt impeachment in 1868. Recently in 1998, President Bill Clinton of US was investigated and found guilty of improper relationship with Monica Lewinsky. He was subsequently impeached. At the state level Gov. James Ferguson of Texas was indicted for embezzlement and later got impeached. In 1923, Gov. John Walton of Oklahoma was impeached after he had been indicted by a grand jury. Gov. Evan Meacham of Arizona was also impeached in 1988 after he had been indicted by a jury. Without investigation, none of these would have been possible. Why should we protect our own governors from Investigation?

\subsection{Canada and Britain}

There is no immunity in the Canadian Constitutional Act of 1867 and even the amendments carried out in 1982. Any public officer will be held responsible for his actions and inactions. One is not sure if the unwritten constitution of Britain will immunize the Prime Minister or the Queen from criminal prosecution, although the popular saying is "the queen is always right."

\subsection{France}

The French Constitution has some degree of immunity for the Parliamentarians and the President. Article 68 of France Constitution [Liability of President and Government] is presented below

(1) The President of the Republic shall not be held accountable for actions performed in the exercise of his office except in the case of high treason. He may be indicted only by the two Assemblies ruling by identical vote in open balloting and by an absolute majority of their members. He shall be tried by the High Court of Justice.

(2) The members of the Government shall be criminally liable for actions performed in the exercise of their office and deemed to be felonies or misdemeanours at the time they were committed. The procedure defined above shall be applied to them and to their accomplices, in the case of a conspiracy against the security of the State. In the cases provided for by this paragraph, the High Court shall be bound by the definition of felonies and misdemeanours, as well as by the determination of penalties as laid down by the criminal law in force when the acts are committed.

\section{The Rule of Law Must Be Strictly Observed}

The great American journalist and essayist, Thomas Paine, wrote, “.... as in absolute governments, the king is law, so in free countries the law ought to be king; and there ought to be no other." (Note 21)

A major democratic thought that contrasts greatly with the concept of immunity is equality before the law, one of the branches of the rule of law. Under the doctrine of the rule of law, the law stands supreme and cannot be manipulated to suit anybody. If a poor man is tried for stealing a phone, the president should also be tried for committing the same offence. In Nigeria the reverse is the case. While the poor and common man languish in prison for petty offences as little as stealing a chicken, few tubers of yam, among others, the rich and influential (most of whom belong to the ruling political class) who are guilty of much more serious crimes walk the streets as free men.

Immunity of this sort negates the principle of equality before the law, a cardinal aspect of the rule of law. Every civilized society must practice at least the fundamentals of the rule of law. The concept of the rule of law is based on the principle that the law is supreme and is the source and foundation of all civilized societies. Its main thrust is to establish the freedom of the citizen and protect him from arbitrary use of power by public authorities. The rule of law adds meaning to the concept of rights. All persons must be seen to be equal before the law. There should be no undue privileges and discrimination in society.

In the case of Fawehinmi v. Inspector General of Police (Note 22), Governor Bola Ahmed Tinubu had sworn to an affidavit at the High Court Ikeja in respect of lost certificates and stated in some of the paragraphs that he attended the University of Chicago from 1972 - 75 and Chicago State University from 1977 - 1979 and obtained 
a BSC Degree in Economics, BSC Degree in Business Administration and qualified as a certified public accountant. On Independent National Electoral Commission (INEC) Form CF001 Tinubu also swore that he attended Government College Ibadan from 1969 - 1971, University of Chicago from 1972 to 1976 and Chicago State University from 1977 - 1979. Chief Gani Fawehinmi (of blessed memory) called into question these declarations or depositions and after thoroughly investigating them himself and believing that they were not true, he wrote the Inspector General of Police requiring him to investigate the allegations as they constituted a crime and a violation of sections $191 \& 192$ of the Criminal Code Act. (Note 23) The court held that while he was immune from prosecution, he was not immune from investigation. This decision calls to question what becomes of the effect of such an investigation. In other words, if such investigations are made and the executive in question is found to have actually committed the crime what happens? By section 308 , he enjoys his immunity while fellow non-executive Nigerians found to have committed the same crime will be tried and sent to jail. This clearly shows that some people can still attain certain exalted positions and enjoy constitutional immunity even when, by their records, they do not deserve such legal protection at all. These allegations called for investigation, yet they were not investigated.

The immunity clause was inserted by the drafters of the Constitution in their wisdom, but unfortunately, Nigeria is a country where every provision of the law is abused to suit selfish ends. Though our law may not be perfect as there is no perfect law under the sun, the operators of the law must ensure that they obey the provisions as we have them, rather than apportioning the blame on the "inadequacies" of the law. We must ensure that there is a real separation of powers as guaranteed by the 1999 Constitution, with the principle of checks and balances. In a jurisdiction like Nigeria where the system of checks and balances is not fully developed, and where the other arms of government have not been substantially empowered, it amounts to class suicide to retain the immunity clause. The courts should always interpret the Constitution and other laws in a manner that will ensure that the rule of law is promoted.

Immunity, as contained in the Nigerian Constitution, legally raises the beneficiaries above the State and the law of the land. In modern government, where the ruled and rulers are deemed equal because the latter are the representatives of the former in government, there is no place for immunity. What happens if a party to a case involving a sitting protected officer dies? It is quite strange that an individual's claim should hang in the balance for so long before he can pursue or address his rights. Our Constitution should provide for Private Independent Prosecutors who would take up the duty of prosecuting corrupt officers in public and private services where the State agents decide to turn a blind eye for political expediency. Also, the Constitution might be amended to bar the executive from instituting legal proceedings in his personal capacity while enjoying absolute immunity, for those who live in glass houses should not throw stones and equality is equity.

\section{Recommendations and Conclusion}

Immunity clause or not, how many governors whose tenures have ended have been successfully prosecuted in Nigeria? The judiciary has an important role to play. They should stop granting frivolous remedies and judgments. Governors have access to state funds which can be used to corruptly sway our weak judiciary. So the judiciary needs to be worked on. As long as our judiciary remains partisan and compromised the presence or otherwise of the immunity clause in the constitution will not really make a difference. Is it wise to depend on governments of foreign countries to arrest and try our governors?

History has shown that our problems are not because of lack of good laws and policies. Our problems are about implementation of the laws. We can make the best laws or policies in the world but without the water-tight implementation devoid of politics, we are deceiving ourselves. We can make the best laws but if the implementation is suspect, nothing would come out of it. The provisions of the constitution, if properly implemented, are enough to check our corrupt leaders. A society that has good governance, whose leaders are accountable, will not belabour itself with whether to expunge the immunity clause or to retain it.

As a writer has suggested, what we ought to do is to redefine and delicately delineate actions that qualify and meet the standards or thresholds that are henceforth set, upon which a governor or president may successfully invoke the immunity clause. There have been cases where public officials have been accused of corruption and embezzlements or engaging in arsons to cover up egregiously heinous crimes. Further, there have been cases of public officials engaging in criminal conspiracies to pervert public interest, national interests, and general public good. These instances merit thorough investigations and determinations, whether such public official's notorious misconducts warrant the stripping of immunity. (Note 24)

The Justice Alfa Belgore committee set up by President Goodluck Jonathan had recommended the removal of the clause. In the present and previous governments, panels and committees have been set up to look into one 
thing or the other. Many reports have been submitted with no one in particular being implemented as recommended. It is time to change this attitude.

The world has become a global village. Politicians can no longer stash wealth in any foreign bank without detection. Money laundering is a crime anywhere in the world and any suspicious activities in any bank account especially in the United States are reported to the authorities by the respective banks. Now, it is more difficult and risky to successfully launder funds anywhere in the world without Nigerians and many nosy press people knowing about it.

As the controversy rages in Nigeria regarding absolute immunity for public officials, Nigerians must however proceed cautiously, in view of the far-reaching implications of our hasty actions that are probable, as we seek to ensure that immunity protections are not exploited by corrupt officials' avaricious perversity and absurdly extreme misuse of power. In this connection, whatever action to be taken in relation to the concept of immunity from prosecution for certain public officials must be undertaken with all seriousness. We must not change the constitution because of the shenanigans of Nigeria's current crop officeholders alone. Constitutional reviews and amendments must be undertaken for a more important rationale and purpose, a solution that would stand the test of time and endure.

Whether the clause is removed or not, emphasis should be placed on creating the enabling environment for enduring democracy through true separation of powers, free press, corruption free judiciary, formation of functional and competent public prosecution process, electoral reforms, change in value system and the promotion of good governance. It is time for all Nigerians to uphold and defend this fundamental principle of equal justice for all, which is one of the most important principles in a democracy.

\section{References}

Absolute immunity for the executive is bad for Nigeria. (2009, February 3). Retrieved from http://saharareporters.com/article/absolute-immunity-executive-bad-nigeria

Adujie, P. I. (December 29, 2004). Immunity from prosecution: Arguing both sides! Retrieved from $\mathrm{http} / /$ kwenu.com/publications/adujie/immunity_prosecution.htm

Akintokunbo, A. A. (n. d.). Immunity Clause: To Stay or Not To Stay. Retrieved from http://www.gamji.com/article6000/NEWS7818.htm

Bryan, A. G. (Ed.). (2004). Blacks' Law Dictionary (8th ed.).

Kehinde, S. The Immunity Clause under the Nigerian 1999 Constitution-A Curse or Blessing? Retrieved from $\mathrm{http} / /$ thelawyerschronicle.com/index.php?option $=$ com_content\&view $=$ article\&id $=54$ :

the-immunity-clause-under-the-nigerian-1999-constitution-\&catid=39: constitutional-law\&Itemid $=43$

News Admin. (2012, December 22). Immunity Clause: Nigerian Leaders' 'Licence to Loot'. Retrieved from http://thestreetjournal.org/2012/12/immunity-clause-nigerian-leaders\%E2\%80\%99-\%E2\%80\%9C licence-to-loot $\% \mathrm{E} 2 \% 80 \% 9 \mathrm{D} /$

\section{Notes}

Note 1. Bryan A. Garner (Ed.), $8^{\text {th }}$ Edition, 2004 at page 765.

Note 2. Edward J. Kionka, Torts in a Nutshell, 341 ( $2^{\text {nd }}$ Edition, 1992).

Note 3. Amaechi v. INEC 2008 Vol. 1 MJSC 1 [P. 6 Para. 1].

Note 4. Ibid [P. 6-7, Para.1] In this case to ask Amaechi to wait till the end of Omehia's tenure of office as Governor before pursuing his suit is to destroy forever his right of action. See also Obih v Mbakwe (1984) SCNLR 192.

Note 5. [2001] 45 WRN 1.

Note 6. The immunity is over and above diplomatic immunity; therefore waiver of any kind does not arise. Also, in the case of Rotimi and Ors V Macgregor (1974) 11 SC 133 the Supreme Court stated as follows: "The provisions of section 161 of the Constitution [1963] are peremptory and admit of no waiver and the introductory words of the section clearly assert the supremacy of the provisions over any other laws including the laws of pleading."

Note 7. Alamieyeseigha v Teiwa [2003] 33 WRN 144.

Note 8. Samuel Igbe v His Excellency Prof. Ambrose Alli (1981) 1 NCLR 129. 
Note 9. Chief Victor Olabisi Onabanjo v Concord Press of Nigeria (1981) 2 NCLR 399; Global Excellence Communications Ltd v Duke [2007] 16 NWLR (Pt. 1059) 22.

Note 10. Paul I. Adujie Immunity from prosecution: Arguing both sides! Available at http://kwenu.com/publications/adujie/immunity_prosecution.htm. Accessed on Tuesday $19^{\text {th }}$ February 2013 [paraphrased].

Note 11. Ibid.

Note 12. Solomon Kehinde, The Immunity Clause under the Nigerian 1999 Constitution-A Curse or Blessing? Available at http://thelawyerschronicle.com/index.php?option=com_content\&view=article\& id=54:the-immunity-clause-under-the-nigerian-1999-constitution-\&catid=39:constitutional-law\&Itemid=43 Accessed on Tuesday $19^{\text {th }}$ February 2013

Note 13. Paul I. Adujie, op. cit.

Note 14. Immunity Clause: Nigerian Leaders' "Licence To Loot" By News Admin on December 22, 2012. Available at http://thestreetjournal.org/2012/12/immunity-clause-nigerian-leaders $\% \mathrm{E} 2 \% 80 \%$ $99-\%$ E2\%80\%9Clicence-to-loot $\%$ E2\%80\%9D/. Accessed on Tuesday $19^{\text {th }}$ February 2013

Note 15. Akintokunbo A Adejumo, Immunity Clause: To Stay Or Not To Stay", available at http://www.gamji.com/article6000/NEWS7818.htm

Note 16. Ibid. [paraphrased]

Note 17. Solomon Kehinde, op. cit [paraphrased]

Note 18. Immunity Clause: Nigerian Leaders' "Licence To Loot" op. cit.

Note 19. "Absolute immunity for the executive is bad for Nigeria" Posted: February 3, 2009. Available at $\mathrm{http} / / /$ saharareporters.com/article/absolute-immunity-executive-bad-nigeria. Accessed on Tuesday $19^{\text {th }}$ February 2013

Note 20. Akintokunbo A Adejumo, op. cit.

Note 21. Quoted in "Absolute immunity for the executive is bad for Nigeria" (Note 20).

Note 22. Supra.

Note 23. Now Cap. C38 LFN 2004.

Note 24. Paul I. Adujie, op. cit.

\section{Copyrights}

Copyright for this article is retained by the author(s), with first publication rights granted to the journal.

This is an open-access article distributed under the terms and conditions of the Creative Commons Attribution license (http://creativecommons.org/licenses/by/3.0/). 